\title{
RIPARIAN AND SWAMP FORESTS AND SCRUB OF THE PINÉ PLATEAU (TRENTINO, NORTHERN ITALY)
}

\author{
Franco PEDROTTI \\ Department of Biosciences, University of Camerino \\ Via Pontoni 5, I-62032 Camerino, Italy \\ e-mail: franco.pedrotti@unicam.it
}

\begin{abstract}
The riparian and swamp forests/scrub of black alder (Alnus glutinosa), white alder (Alnus incana), grey willow (Salix cinerea) and bay willow (S. pentandra) of the Piné Plateau (Trentino, central Alps) are described here in terms of their floristic composition. They are assigned to the following associations: Filipendulo vulgarisAlnetum glutinosae, Stellario nemorum-Alnetum glutinosae, Carici elongatae-Alnetum glutinosae, Carici elataeAlnetum glutinosae, Frangulo-Salicetum cinereae and Salicetum pentandro-cinereae. In addition, information regarding the distribution of the previous woody communities in the Trentino-Alto Adige Region and their corresponding vegetation series and geosigmeta are provided.
\end{abstract}

Keywords: Alnion glutinosae, Alnion incanae, colluvial fan, floodplain, geosigmetum, cessation of mowing, Salicion cinereae, slope spring, vegetation sigmetum, wet meadows.

\section{Introduction}

The main purpose of this study is to describe floristically and syntaxonomically the riparian/swamp forests of black alder (Alnus glutinosa) and white alder (Alnus incana), as well as the swamp scrub of black willow (Salix cinerea) and bay willow ( $S$. pentandra), from the Piné Plateau (Trentino, northern Italy).

In a mountainous area, such as that of the Trentino-Alto Adige Region, swamp forests (Alnion glutinosae) are very rare due to the complex geomorphology and are limited to the bottom of some wide-bed valleys and to flat landforms, such as plateaux. These habitats have undergone profound environmental changes over the centuries, consisting of reclamation, drainage, conversion to agricultural areas, etc. That is why riparian and swampy, woody vegetation has almost disappeared in the Trentino-Alto Adige Region, except for a few residual patches and strips. Given its flat morphology, the Piné Plateau represents - to some extent - an exception to the general situation.

\section{Materials and Methods \\ Study area}

Geomorphologically, the Piné Plateau (Trentino) represents a valley suspended above the Cembra Valley, a nearby and deeper valley derived by glacial over-excavation and river erosion. The plateau extends between 800 and $1200 \mathrm{~m}$ altitude, in the extreme foothills of the Lagorai Mountains Group. The geological substrate is represented by Permian, quartziferous porphyry of various ages and types. 
The Piné Plateau is at the border between the pre-Alpic and Alpic bioclimatic sectors [9]. The valley bottom is characterized by a supratemperate bioclimate [23]. In the locality of Piazze di Piné (1067 m) the average annual rainfall reaches $1151 \mathrm{~mm}$ [11].

The plateau is crossed by the Silla stream, which springs from the Lago delle Piazze, from which the "Foss Grant" or "Rogia" emerges, which, after two kilometres, flows into the Serraia Lake. As an emissary of the Lago della Serraia, the Silla stream crosses the villages of Baselga di Piné and Tressilla to then descend decisively downstream and flow into the Fersina stream. The Rio Brusago and Rio Regnana cross the plateau transversely and therefore their waters enter the Avisio basin. Along these streams riparian forests of white alder (Alnus incana) have developed.

The riparian black alder forests (Alnus glutinosa) have developed along the banks of the waterways that run through the semi-flat and undulating areas of the plateau, which nowadays are very fragmented and man-transformed due to buildings, bridges, roads and similar. There are also some small lateral tributaries, of limited flow, such as the one that descends from the slopes of Monte Costalta and pours into Lago della Serraia at the colluvial fan located south of the lake.

Another watercourse of some importance is the Rio Negro, a stream that originates in the "Palustela" locality, near Miola (now completely urbanized), that belongs to the Fersina and not to the Avisio basin. On the vegetation map of the Trento Sheet (scale 1: 50,000), which also includes the Piné Plateau, the aforementioned riparian forests were mapped as Alnetum glutinosoincanae Braun-Blanquet 1915, a generic association which was subsequently divided into well differentiated associations, as reported here. On the plateau, there are several basins of glacial excavation or of mixed origin (glacial, alluvial barriers, fans, moraine deposits, etc.). gbogs and marshes (Lago delle Piazze, Lago della Serraia, Laghestel, Laghetto delle Rane) which support reduced strips of Alnus glutinosa woods and scrub of Salix pentandra and S. cinerea.

\section{Vegetation data and interpretation}

The vegetation surveys were carried out by using the phytosociological methodology of Braun-Blanquet [5, 6]. The forest communities of the order Populetalia albae were syntaxonomically assigned by following the proposal of Bensettiti et al. (2001), the swamp forests the proposal of Douda (2008). The interpretation of the vegetation cover at landscape and geographical levels was done through the serial and catenal approach, according to Bioret et al. (2019) and Pedrotti (2019).

\section{Results and Discussion Riparian forests}

\section{Filipendulo ulmariae-Alnetum glutinosae}

Filipendulo ulmariae-Alnetum glutinosae (Lemée 1937) Passarge 1968 [syn. Macrophorbio-Alnetum glutinosae (Lemée 1937) Maas 1959] is the most common and widespread riparian association on the Piné Plateau (Table 1).

In a note on the vegetation series and geoseries of the Piné Plateau, the presence of another riparian association of black alder, Stellario nemorum-Alnetum glutinosae facies with Filipendula ulmaria, was reported [23]. However, based on the observations and surveys carried out in 2019, the alder communities with Filipendula ulmaria should be assigned to Filipendulo ulmariae- 
Alnetum glutinosae. Therefore, on the Piné Plateau two riparian associations of black alder are present: Stellario nemorum-Alnetum glutinosae and Filipendulo ulmariae-Alnetum glutinosae.

Table 1: Filipendulo vulgaris - Alnetum glutinosae

\begin{tabular}{|c|c|c|c|c|c|c|c|c|}
\hline Relevé number & 1 & 2 & 3 & 4 & 5 & 6 & 7 & \\
\hline Altitude (m a.s.1.) & 975 & 972 & 972 & 980 & 970 & 910 & 1990 & \\
\hline Aspect & - & S-W & - & $\mathrm{N}$ & - & N-W & - & \\
\hline Slope (degrees) & - & 3 & - & 5 & - & 5 & - & రి \\
\hline Tree cover $(\%)$ & 100 & 100 & 100 & 100 & 100 & 80 & 90 & 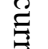 \\
\hline Shrub cover $(\%)$ & 15 & 15 & 15 & 15 & 20 & 15 & 15 & $\overrightarrow{9}$ \\
\hline Herb cover $(\%)$ & 100 & 100 & 100 & 100 & 100 & 100 & 100 & $\overparen{\varnothing}$ \\
\hline Overall cover $(\%)$ & 100 & 100 & 100 & 100 & 100 & 100 & 100 & \\
\hline Number of species & 17 & 20 & 20 & 20 & 22 & 22 & 21 & \\
\hline Area $\left(\mathrm{m}^{2}\right)$ & 100 & 100 & 100 & 100 & 100 & 80 & 80 & \\
\hline \multicolumn{9}{|c|}{ Differential species of association } \\
\hline Filipendula ulmaria & 5.5 & 4.4 & 2.2 & 2.2 & 5.5 & 3.3 & 4.4 & 7 \\
\hline Scirpus sylvaticus & 1.1 & 1.1 & 1.1 & 3.3 & 1.1 & 1.1 & 1.1 & 7 \\
\hline Lysimachia vulgaris & + & $\cdot$ & $\cdot$ & + & $\cdot$ & + & + & 4 \\
\hline \multicolumn{9}{|c|}{$\begin{array}{l}\text { Character species of Alnion incanae and } \\
\text { Populetalia albae }\end{array}$} \\
\hline Alnus glutinosa (tree) & 5.5 & 5.5 & 5.5 & 5.5 & 5.5 & 5.5 & 3.3 & 7 \\
\hline Alnus glutinosa (shrub) & . & . & . & 1.1 & . & . & . & 1 \\
\hline Rubus caesius p.p. & + & + & + & + & + & + & + & 7 \\
\hline Elymus caninus & + & . & . & . & + & + & . & 3 \\
\hline Sambucus nigra & . & + & + & . & + & . & . & 3 \\
\hline Humulus lupulus & . & + & + & . & . & + & . & 3 \\
\hline Stachys sylvatica & . & 1.1 & . & + & . & . & + & 3 \\
\hline Impatiens noli-tangere & . & + & . & + & . & . & . & 2 \\
\hline Viburnum opulus & . & . & . & + & . & + & . & 2 \\
\hline Prunus padus (shrub) & . & . & . & + & . & . & . & 1 \\
\hline Festuca gigantea & . & . & . & . & + & . & . & 1 \\
\hline Stellaria nemorum & . & . & . & . & . & + & . & 1 \\
\hline \multicolumn{9}{|c|}{ Character species of Querco-Fagetea } \\
\hline Fraxinus excelsior (tree) & . & + & + & . & + & . & . & 3 \\
\hline Fraxinus excelsior (shrub) & 1.1 & 1.1 & 1.1 & + & 2.2 & 1.1 & + & 7 \\
\hline Acer pseudoplatanus (shrub) & . & . &.+ & . & + & . & . & 2 \\
\hline Galeobdolon luteum & . & . & + & . & . & . & . & 1 \\
\hline Acer campestre (shrub) & . & . & . & . & + & . & . & 1 \\
\hline \multicolumn{9}{|l|}{ Companion species } \\
\hline Urtica dioica & + & 1.1 & 3.3 & + & + & + & 2.2 & 7 \\
\hline Impatiens parviflora & + & + & + & + & + & + & + & 7 \\
\hline Equisetum arvense & + & + & + & 1.1 & + & + & + & 7 \\
\hline Geum rivale & + & . & + & + & + & 1.1 & + & 6 \\
\hline Deschampsia caespitosa & + & . & . & + & 1.1 & 2.2 & + & 5 \\
\hline Rubus idaeus & . & + & + & . & + & + & + & 5 \\
\hline Athyrium filix-femina & + & . & . & + & + & + & . & 4 \\
\hline Salix caprea & . & + & + & . & . & + & 1.1 & 4 \\
\hline Glechoma hederacea & + & . & + & . & . & . & + & 3 \\
\hline Geum urbanum & . & 1.1 & + & . & . & . & + & 3 \\
\hline Agrostis stolonifera & . & + & + & . & . & . & + & 3 \\
\hline Ranunculus repens & . & + & . & . & + & + & . & 3 \\
\hline Sorbus aucuparia (shrub) & . & . & + & + & + & . & . & 3 \\
\hline
\end{tabular}




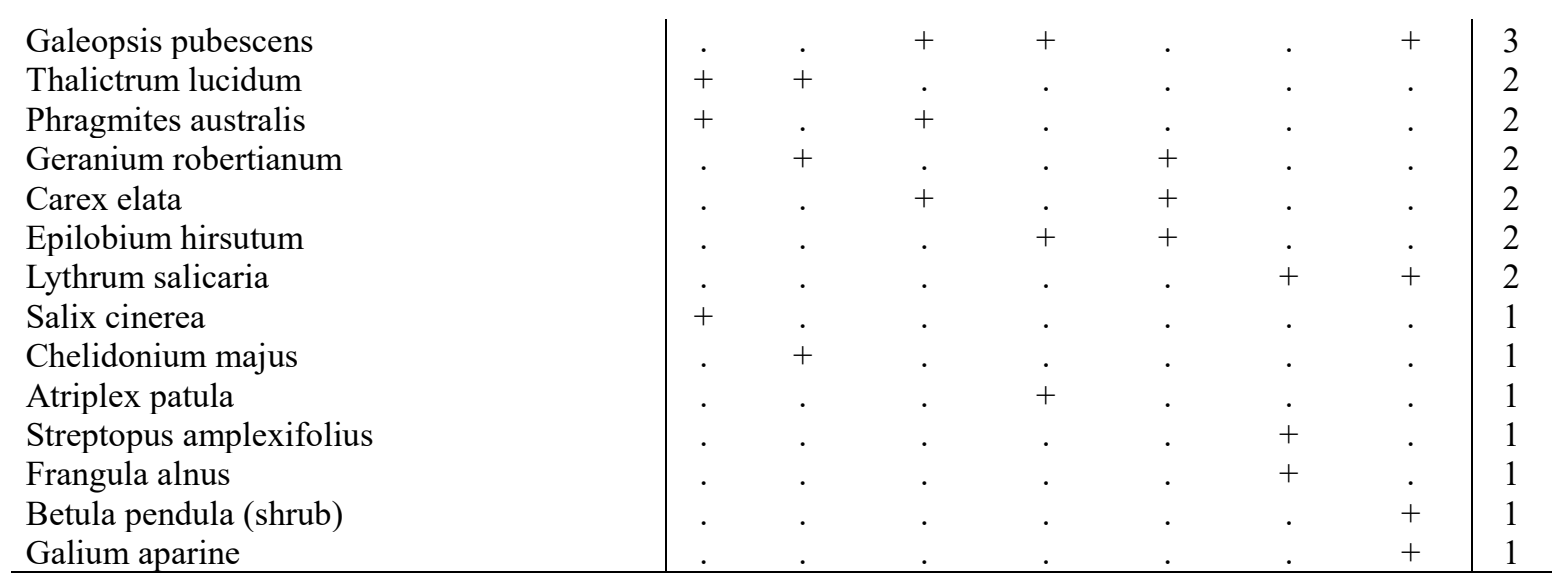

Location and date of the releves:

1 - Serraia Lake (northern shores), , 20-VIII-2019; 2 - Serraia Lake (northern colluvial fan), 20-VIII-2019; 3 Serraia Lake (northern shores), 20-VIII-2019; 4 - Serraia Lake (southern colluvial fan); 19-VIII-2019; 5 between Guarda and Buss, 21-VIII-2019; 6 - Laghestel, 22-VIII-2019; 7 - between Centrale and Brusago, 24VIII-2019.

These woods are formed of a dense and compact layer of Alnus glutinosa, with the constant occurrence of Fraxinus excelsior, which is, however, more frequent in the shrub layer (Table 1). Among the shrubs, Prunus padus, which has an irregular distribution in Trentino, is worth noting as it has only recently been observed on the Piné Plateau [28]. The undergrowth is dominated by some forbs such as Filipendula ulmaria, Scirpus sylvaticus and Lysymachia vulgaris. Actually, the old, invalid name of Macrophorbio-Alnetum glutinosae referred to the presence of megaforbs. The French authors also call it “aulnaie à hautes herbes”. Unlike for the class Querco-Fagetea, the character species of the order Populetalia albae are well represented. The species richness per relevé varies between 17 and 22 .

This black alder community develops under any of the following site conditions: a) alluvial terraces on valley bottoms and river terraces along streams that flood the alder forests on one or both sides, sometimes giving rise to small swamps (Fig. 1a); b) flat colluvial fans with resurgences (Fig. 1b); c) gentle slopes with resurgence waters.

The Filipendulo ulmariae-Alnetum glutinosae in Piné is currently in expansion due to the cessation of mowing in wet grasslands (Junco-Molinietum, Scirpetum sylvatici and Lysimachio vulgaris-Filipenduletum) and the triggering of secondary successions [8, 12]. For instance, after 16-20 years (as inferred from the number of annual rings in Alnus glutinosa stumps) from the abandonment of mowing, several black alder woods supporting some nemoral species (Stachys sylvatica, Humulus lupulus, Mycelis muralis, Viola reichenbachiana, Galeobodolon luteum, Melica nutans) have developed (see Table 3 in Pedrotti, 1988a). This is the first stage of development of Filipendulo ulmariae-Alnetum glutinosae. In these newly formed woods, even after 16-20 years, a very abundant layer of Molinia coerulea still persists in the undergrowth, but most of these plants are sterile. In mature woods, Molinia coerulea is never present, while Filipendula vulgaris is able to tolerate the overstorey shade.

Filipendulo ulmariae-Alnetum glutinosae is mainly distributed in central Europe, while being reported here for the first time on the Piné Plateau. To date this is the only known locality for this association in Trentino. 

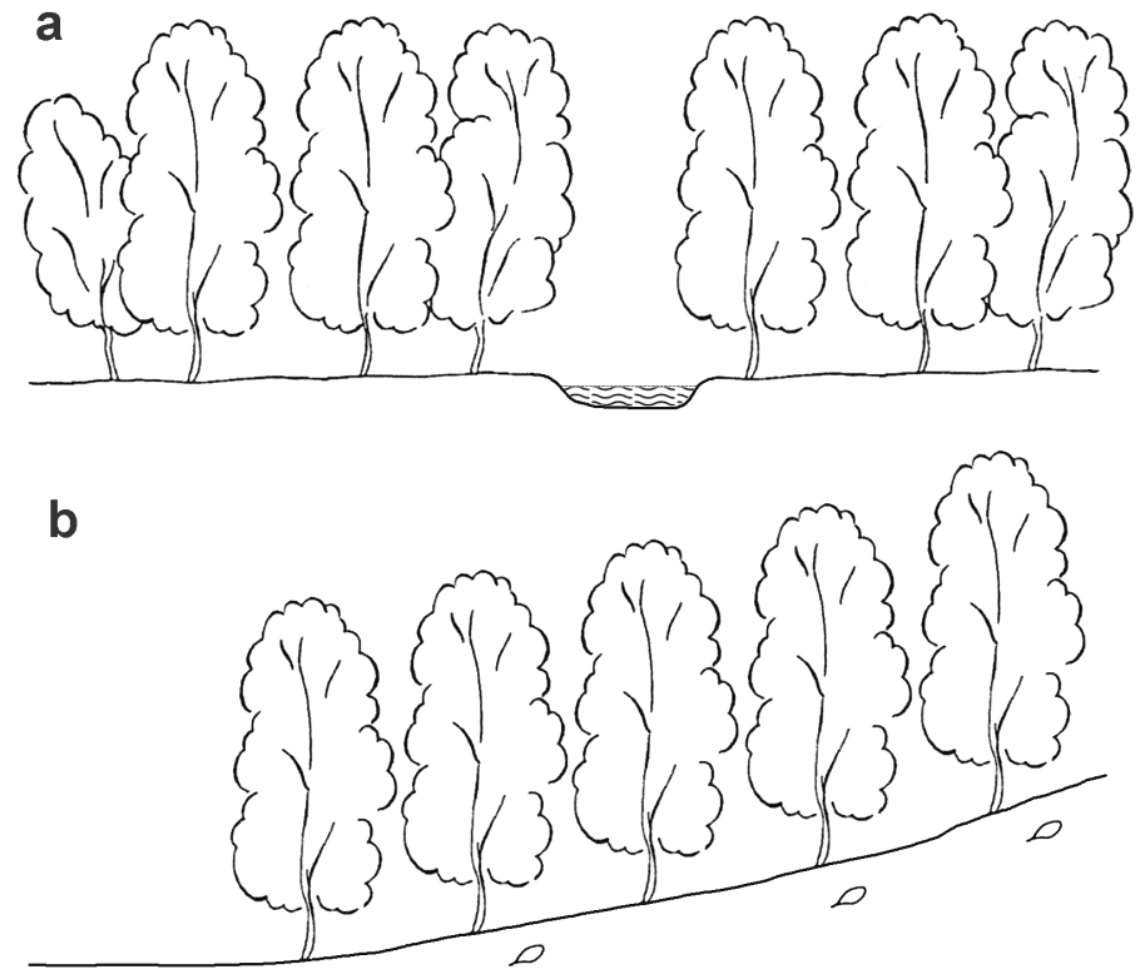

Fig. 1: Filipendulo vulgaris-Alnetum glutinosae developed on alluvial terraces along streams (a) and on mild slopes or colluvial fans featuring spring waters (b).

Stellario nemorum-Alnetum glutinosae

Table 2. Stellario nemorum-Alnetum glutinosae

\begin{tabular}{l|c}
\hline Relevé number & 1 \\
Altitude (m a.s.l.) & 1110 \\
Aspect & $\mathrm{S}-\mathrm{W}$ \\
Slope (degrees) & 10 \\
Tree cover (\%) & 100 \\
Shrub cover (\%) & 20 \\
Herb cover (\%) & 90 \\
Overall cover (\%) & 100 \\
Number of species & 47 \\
Area (m²) & 100 \\
\hline & \\
Differential species of association & \\
& \\
Stellaria nemorum & 1.2 \\
Character species of Alnion incanae and Populetalia & \\
albae & \\
Alnus glutinosa (tree) & \\
Impatiens noli-tangere & \\
Alnus incana (tree) & \\
Sambucus nigra & +.4 \\
Humulus lupulus & + \\
Stachys silvatica & + \\
Agropyron caninum & + \\
&
\end{tabular}




\begin{tabular}{|c|c|}
\hline \multicolumn{2}{|c|}{ Character species of Querco-Fagetea } \\
\hline Acer pseudoplatanus (tree) & 1.1 \\
\hline Fraxinus excelsior (tree) & + \\
\hline Galeobdolon luteum & + \\
\hline Actaea spicata & + \\
\hline Laburnum alpinum & + \\
\hline \multicolumn{2}{|l|}{ Companion species } \\
\hline Deschampsia caespitosa & 1.1 \\
\hline Geum urbanum & 1.1 \\
\hline Athyrium filix-femina & 1.1 \\
\hline Chaerophylum villarsi & 1.1 \\
\hline Lysimachia vulgaris & + \\
\hline Filipendula ulmaria & + \\
\hline Rubus idaeus & + \\
\hline Mycelis muralis & + \\
\hline Viola reichenbachiana & + \\
\hline Urtica dioica & + \\
\hline Streptopus amplexifolius & + \\
\hline Rumex conglomeratus & + \\
\hline Thalictrum aquilegifolium & + \\
\hline Poa nemoralis & + \\
\hline Salvia glutinosa & + \\
\hline Cardamine impatiens & + \\
\hline Ranunculus aconitifolius & + \\
\hline Galeopsis speciosus & + \\
\hline Orchis maculata & + \\
\hline Solidago virgaurea & + \\
\hline Ranunculus repens & + \\
\hline Fragaria vesca & + \\
\hline Convallaria majalis & + \\
\hline Geranium robertianum & + \\
\hline Aegopodium podagraria & + \\
\hline Melandrium rubrum & + \\
\hline Oxalis acetosella & + \\
\hline Tussilago farfara & + \\
\hline Dryopteris filix-mas & + \\
\hline Dryopteris dilatata & + \\
\hline Sorbus aucuparia & + \\
\hline Betula pendula & + \\
\hline Corylus avelana & + \\
\hline Aruncus dioicus & + \\
\hline
\end{tabular}

Location and date of the releves:

1 - Cospian, Fovo Alto (from Pedrotti, 1988a).

This association develops along running watercourses with quite steep banks, so that no swamps can form. It is frequent in small patches along the Silla stream and some lateral tributaries (Table 2). Note that the name Stellario nemori-Alnetum glutinosae, used to designate this association, is wrong, because "nemorum" (from "Stellaria nemorum") is a plural genitive and from a genitive we cannot derive another genitive, "nemori", as has often been used in the literature. The word "nemori" does not exist in Latin vocabulary. In this case, the plural genitive must be retained, so the correct name is Stellario nemorum-Alnetum glutinosae. 


\section{Alnetum incanae}

The riparian white alder forests (Alnus incana), which are widespread in the alpine sector of the entire Trentino-Alto Adige Region, were attributed in the past to Alnetum incanae [25, 27]. A recent syntaxonomic review by Sburlino et al. (2012) assigned these communities to AceriAlnetum incanae Beger 1922.

\section{Swamp forests}

The swamp forests have been eliminated almost everywhere in the valley bottoms, where only some rare residual woods are still present, as in Val Venosta. Residual patches of swamp forests can be found, in a few cases, on the shores of some lakes, a typical case being the elongateshaped Lake Madrano. At its two ends, on the marshy banks, are two stands of Thelypterido palustris-Alnetum glutinosae, which are of great conservation value due to their rarity [14].

\section{Carici elongatae-Alnetum glutinosae}

In Piné, the Carici elongatae-Alnetum glutinosae is developed in a single, very limited area, i.e. in the Sternigo marshes, on the shores of the Serraia Lake. It is a grove of black alder (Alnus glutinosa), spreading over an area of just over $100 \mathrm{~m}^{2}$ and surrounding a spring (Table 3 ).

\begin{tabular}{l|c} 
Table 3: Carici elongatae-Alnetum glutinosae \\
\hline Relevé number & 1 \\
Altitude (m a.s.l.) & 975 \\
Aspect & - \\
Slope (degree) & - \\
Overall cover (\%) & 100 \\
Number of species & 6 \\
Area (m²) & 50 \\
\hline & \\
Alnus glutinosa (tree) & 4.4 \\
Alnus glutinosa (shrub) & 1.1 \\
Carex elongata & 1.2 \\
Phragmites australis & + \\
Lycopus europaeus & + \\
Filipendula ulmaria & + \\
Lemna minor & + \\
\hline
\end{tabular}

Location and date of the releves:

1 - Sternigo, 22-VIII-2001.

\section{Carici elatae-Alnetum glutinosae}

The Carici elatae-Alnetum glutinosae is also very fragmented; there are some groves in the Laghestel basin, in hollows and depressions, even the small ones, with the water table outcropping throughout the year (Table 4). Carici elatae-Alnetum glutinosae represents the potential vegetation of a large part of the Laghestel basin, as illustrated on the vegetation map of Pedrotti (2004).

The two associations Carici elongatae-Alnetum glutinosae and Carici elatae-Alnetum glutinosae are here considered separately, even if some authors have placed them in synonymy [29]. Other swamp forests of Trentino-Alto Adige are Thelypterido palustris-Alnetum glutinosae Klika 1940 (shores of Lake Levico; [16, 17, 18]; Carici acutiformis-Alnetum glutinosae Scamoni 1935 (shores of Lake Idro, Roncegno marshes, wetlands of the lower Valsugana; [15, 26]) and Caltho palustris-Alnetum glutinosae Suchlik 1968 (in Val Venosta; [10]). 
Table 4: Carici elatae-Alnetum glutinosae

\begin{tabular}{l|c}
\hline Relevé number & 1 \\
Altitude (m a.s.1.) & 905 \\
Aspect & - \\
Slope (degrees) & - \\
Overall cover (\%) & 100 \\
Number of species & 7 \\
Area (m²) & 100 \\
\hline & \\
Alnus glutinosa (tree) & 5.5 \\
Carex elata & 2.2 \\
Phragmites australis & 1.1 \\
Valeriana dioica & +.2 \\
Solanum dulcamara & + \\
Deschampsia caespitosa & + \\
Lycopus europaeus & + \\
Location and date of the releves: & \\
1 - Laghestel, 22-VIII-2001 (from Pedrotti, 2004).
\end{tabular}

\section{Swamp scrub}

\section{Frangulo-Salicetum cinereae}

The scrub of Frangulo-Salicetum cinereae (syn. Salicetum cinereae Zolyomi 1931) has formed on the Piné Plateau starting from the years 1980-2000, following the cessation of mowing in the wet meadows of Molinion (Junco- Molinietum, Lysimachio vulgaris-Filipenduletum, Scirpetum sylvatici), nowadays widespread in Laghestel, Palustela di Miola and other locations in Piné. Frangulo-Salicetum cinereae is common in various wetlands in Trentino such as Lake Loppio, Laghestel, Fiavé peat bog, Roncegno swamp, Inghiaie biotope and lower Valsugana [3, $13,15,18,19,21,26]$.

\section{Salicetum pentandro - cinereae}

In the marshes of Sternigo, on the shores of Lago della Serraia, a small group of a few saplings of Salix pentandra and S. cinerea grows, suggesting the presence of Salicetum pentandrocinereae, which is frequent in central and northern Europe, but very rare in the Alps. These groves usually occur in small patches surrounded by grasslands of Caricetum lasiocarpae, Equiseto fluviatilis-Caricetum rostratae and partly, Lysimachio vulgaris-Filipenduletum and Scirpetum sylvatici. In the past, intensive mowing was carried out here, which prevented the establishment of woody species [31]. With the abandonment of mowing, a slow process of secondary succession is now underway, leading to the recovery of the woody species. In the Trentino-Alto Adige Region, Salicetum pentandro-cinereae is present in two other locations: in the Fiavé peat bog $[3,4,16,18]$ and in the upper Val Venosta, along the Adige river, under the Lake of San Valentino alla Muta [27].

\section{Syntaxonomic framework}

In summary, the riparian and marshy forests and scrubs of the Piné Plateau can be included in the following syntaxonomic scheme: 
QUERCO ROBORIS-FAGETEA SYLVATICAE Braun- Blanquet \& Vlieger in Vlieger 1937

Populetalia albae Braun-Blanquet ex Tchou 1948

Alnion incanae Pawłowski in Pawłowski, Sokołowski \& Wallisch 1928

Filipendulo ulmariae-Alnetum glutinosae (Lemée 1937) Passarge 1968

Stellario nemorum-Alnetum glutinosae (Kästner 1938) Lohmeyer 1957

Alnetum incanae Lüdi 1921

ALNETEA GLUTINOSAE Braun-Blanquet et Tüxen ex Westhoff et al. 1946

Alnetalia glutinosae Tüxen 1937

Alnion glutinosae Malcuit 1929

Carici elongatae-Alnetum glutinosae Tüxen 1931

Carici elatae-Alnetum glutinosae Franz 1990

Salicetalia auritae Doing 1962 ex Westhoff in Westhoff \& Den Held 1969

Salicion cinereae Müller \& Görs 1958

Frangulo-Salicetum cinereae Malcuit 1929

Salicetum pentandro - cinereae Almquist ex Passarge 1961

\section{Riparian/swamp vegetation series and geoseries}

The riparian and swamp forest and scrub associations of the Piné Plateau form the following sigmeta:

Filipendulo ulmariae-Alneto glutinosae sigmetum (pre-Alpic sector; floodplains along streams; flattened colluvial fans with stream or spring waters);

- Forest: Filipendulo ulmariae-Alnetum glutinosae

- Scrub: Frangulo-Viburnetum opuli

- Hygrophilous meadow: Filipendulo-Epilobietum hirsuti, Scirpetum sylvatici, Lysimachio vulgaris-Filipenduletum

Stellario nemorum-Alneto glutinosae sigmetum (pre-Alpic sector, along streams);

- Forest: Stellario nemorum-Alnetum glutinosae

- Hygrophilous meadow: Filipendulo-Epilobietum hirsuti, Scirpetum sylvatici, Lysimachio vulgaris-Filipenduletum

- Synanthropic vegetation: Juncetum macri, Echinochloo-Polygonetum lapathifolii, Arctietum lappae

Saliceto albae sigmetum (fragments) (Alpic and pre-Alpic sectors; along streams);

- Forest: Salicetum albae

Alneto incanae sigmetum (Alpic sector, along streams);

- Forest: Alnetum incanae

- Pioneer vegetation: Epilobietum fleischeri

Carici elongatae-Alneto glutinosae sigmetum (Alpic sector, lake basins);

- Forest: Carici elongatae-Alnetum glutinosae

- Scrub: Frangulo-Salicetum cinereae (partially) 
- Hygrophilous meadow: Scirpetum sylvatici, Lysimachio vulgaris-Filipenduletum

- Reed thicket: Phragmitetum vulgaris

Carici elatae-Alneto glutinosae sigmetum;

- Forest: Carici elatae-Alnetum glutinosae

- Scrub: Frangulo-Salicetum cinereae (partially)

- Marshy meadow: Caricetum elatae

- Hygrophilous meadow: Alopecuretum pratensis, Scirpetum sylvatici, Lysimachio vulgarisFilipenduletum

- Reed thicket: Phragmitetum vulgaris

Frangulo-Saliceto cinereae sigmetum (pre-Alpic and Alpic sectors; lake basins and floodplains); - Scrub: Frangulo-Salicetum cinereae

- Hygrophilous meadow: Junco-Molinietum, Scirpetum sylvatici, Lysimachio vulgarisFilipenduletum

Saliceto pentandro - cinereae sigmetum (Alpic sector; lake basins).

- Forest: Salicetum pentandro - cinereae

- Peaty meadow: Caricetum lasiocarpae, Equiseto fluviatilis-Caricetum rostratae

The list of geosigmeta, which include the riparian and swampy wood communities of the Pinè Plateau, is presented below. For every geosigmetum, the following information is reported: geomorphology, habitat, phytoclimatic sector, component sigmeta.

\section{Narrow valleys}

Alpic geoseries of narrow valleys along streams, in the Alpic sector; constitutive sigmeta: Alneto incanae [Rio di Brusago, Rio di Regnana]

Pre-Alpic geoseries of narrow valleys along streams, in the Alpic sector; constitutive sigmeta: Stellario nemorum-Alneto glutinosae [Rio Fovo Alto, Rio Silla]

\section{Floodplains}

Pre-Alpic-Alpic geoseries of floodplains (along streams); constitutive sigmeta: Stellario nemorum-Alneto glutinosae, Filipendulo vulgaris-Alneto glutinosae; Frangulo-Salicetum cinereae [between Brusago and Centrale]

\section{Colluvial fans}

Prealpic-alpic, acidophilous (porphyritic) geoseries of colluvial fans with streams or spring waters; constitutive sigmeta: Filipendulo vulgaris-Alneto glutinosae, Stellario nemorum-Alneto glutinosae [Sternigo, south of Serraia Lake]

\section{Slopes}

Pre-Alpic-Alpic, acidophilous (porphyritic) geoseries of slopes with spring waters; constitutive sigmeta: Filipendulo ulmariae-Alneto glutinosae [Fovo Alto, Laghestel] 


\section{Lake basins}

Pre-Alpic-Alpic geoseries of ancient lake basins; constitutive sigmeta: Carici elongataeAlneto glutinosae; Carici elatae-Alneto glutinosae; Saliceto pentandro-cinereae sigmetum; Frangulo-Saliceto cinereae sigmetum [north of Serraia Lake, Laghestel, Palustela, near Miola].

\section{REFERENCES}

1. Bensettiti, F., Rameau, J.-C., Chevalier, H. (eds.), 2001, Habitats forestiers, «Cahiers d'habitats», Natura 2000, 1: $1-423$.

2. Bioret, F., Boullet, V., Choisnet, G, Roux, C., Thébaud, G., Panaïotis, C., Chalumeau, A., Delbosc, P., Demartini, C., Gauberville, C., Cianfaglione, K., Bensettiti, F., Lalanne, A., 2019, Landscape phytosociology concepts and definitions applied to serial and catenal vegetation mapping, Contrib.Bot., 54: 47-54.

3. Canullo, R., Pedrotti, F., Venanzoni, R., 1991, Les processus dynamiques dans la végétation de la tourbière de Fiavé (Italie du Nord). Phytocoenosis, 3(N.S.), Suppl. Cartograf. Geobot., 2: 189-194.

4. Canullo, R., Pedrotti, F., Venanzoni, R., 1994, La Torbiera di Fiavé. In: Pedrotti, F. (ed.), Guida all'escursione della Società Italiana di Fitosociologia in Trentino (1-5 luglio 1994), Camerino, Dipartimento Botanica ed Ecologia: 78-110.

5. Cristea, V., Gafta, D., Pedrotti, F., 2004, Fitosociologie, Cluj-Napoca, Presa Universitară Clujeană.

6. Cristea, V., Gafta, D., Pedrotti, F., 2015, Fitosociologia, Trento, Temi.

7. Douda, J., 2008, Formalized classification of the vegetation of alder carr and floodplain forests in the Czech Republic, Preslia, 80: 199-224.

8. Gafta, D., Canullo, R., 1992, The role of Alnus glutinosa (L.) Gaertn. In the secondary succession on wet meadows in the Piné high plain (North Italy), Studia Geobotanica, 12: 105-120.

9. Gafta, D., Pedrotti, F., 1998, Fitoclima del Trentino-Alto Adige, St. Trent. Sc. Nat., 73: 55-11.

10. Pedrotti, F., 1980 - Guida all'escursione della Società Botanica Italiana in Val d'Adige e nel Parco Nazionale dello Stelvio (27-30 giugno 1980). Camerino, Centro Stampa Università.

11. Pedrotti, F., 1981, Carta della vegetazione del Foglio Trento, Consiglio Nazionale Ricerche, AQ/1/1/: 1- 38.

12. Pedrotti, F., 1988a, Alterazioni del paesaggio delle montagne del Trentino a seguito dei cambiamenti dell'uso del suolo, Colloques Phytosociologiques, XVII: 207-220.

13. Pedrotti, F., 1988b, La flora e la vegetazione del Lago di Loppio (Trentino), Giorn. Bot. Ital., 122(3-4): 105147.

14. Pedrotti, F., 1990, Nota sulla flora e sulla vegetazione del Lago di Madrano (Trentino), Inform. Bot. Ital., 22(3): 182-193.

15. Pedrotti, F., 1995, Nota sulla vegetazione degli ambienti umidi della bassa Valsugana (Trentino), Doc. Phytosoc., XV: 417-449.

16. Pedrotti, F., 1997, Geobotanik und Landschaftskartierung - Beispiele aus Italien. Ber. Reinh, Tuxen Ges., 9: 123-137.

17. Pedrotti, F., 1998, La cartographie géobotanique des biotopes du Trentin (Italie), Écologie, 29(1-2): 105-110.

18. Pedrotti, F., 2001, Biotopkartierung in Trentino: Methoden und resultate, Sauteria, 11: 61-74.

19. Pedrotti, F., 2003, Il biotopo delle Inghiaie in Trentino, La Riserva Naturale di Torricchio, 11(3): 347-355.

20. Pedrotti, F., 2004, Ricerche geobotaniche al Laghestel di Piné (1967-2001), Braun-Blanquetia, 35: 1-55.

21. Pedrotti, F., 2006, Die Änderungen der Vegetation in Feuchtgebieten des Trentino in den letzen 50 Jahren. Sauteria, 14: 133-149.

22. Pedrotti, F., 2013, Guida all'escursione della Società Botanica Italiana al Lago della Serraia (Altopiano di Piné), Firenze, Società Botanica Italiana.

23. Pedrotti F., 2017, Three-dimensional maps of vegetation series and geoseries with the use of stereograms, Contrib.Bot., 52: 55.67.

24. Pedrotti, F., 2019, Geoseries interpretation and mapping, Contrib.Bot., 54: 55-75. 
25. Pedrotti, F., Cortini Pedrotti, C., 2005, Alnetum incanae in the Val di Lamare (Ortles-Cevedale Group). In: Pedrotti, F., Pedrotti, L. (eds.), Stelvio Seventy Conference. 8-11 September 20095. Rabbi Valley (Trentino), Italy. Trento, TEMI: 191-192.

26. Pedrotti, F., Gafta, D., 1994, La Palude di Roncegno. In: Pedrotti F. (ed.), Guida all'escursione della Società Italiana di Fitosociologia in Trentino (1-5 luglio 1994), Camerino, Dipartimento Botanica Ecologia: 123-129.

27. Pedrotti, F., Gafta, D., 1996, Ecologia delle foreste ripariali e paludose dell'Italia, L'Uomo e l'Ambiente, 23: 1163.

28. Prosser, F., Bertolli, A., Festi, F., Perazza, G, 2019, Flora del Trentino, Rovereto, Osiride.

29. Sburlino, G., Poldini, L., Venanzoni, R., Ghirelli, L., 2011, Italian black alder swamp: their syntaxonomy relationship and originality within the European context, Plant Biosystems, 145: 148-171.

30. Sburlino, G., Poldini, L., Andreis, C., Giovagnoli, L., Tasinazzo, S., 2012, Phytosociological overview of the Italian Alnus incana-rich riparian woods, Plant Sociology, 49(1): 39-53.

31. Venanzoni, R., 1988, I prati umidi (Calthion) del Lago della Serraia (Trentino), Coll. Phytosoc., XVI: 835-845.

\section{PĂDURI ȘI TUFĂRIȘURI RIPARIENE ȘI DE MLAȘTINĂ DIN PLATOUL PINÉ (TRENTINO, NORDUL ITALIEI)}

\section{(Rezumat)}

Pădurile/tufărișurile ripariene și de mlaștină de arin negru (Alnus glutinosa), arin alb (Alnus incana), salcie cenușie/zălog (Salix cinerea) și salcie (S. pentandra) din Platoul Piné (Trentino, Alpii centrali) sunt descrise din punctul de vedere al compoziției floristice. Acestea sunt încadrate în următoarele asociații: Filipendulo vulgarisAlnetum glutinosae, Stellario nemorum-Alnetum glutinosae, Carici elongatae-Alnetum glutinosae, Carici elataeAlnetum glutinosae, Frangulo-Salicetum cinereae și Salicetum pentandro-cinereae. În plus, sunt furnizate și informații cu privire la distribuția comunităților forestiere precedente din Regiunea Trentino-Alto Adige și corespondența cu seriile de vegetație și geosigmeta. 